\title{
夏期登山の疲労について
}

\section{Studies on the Fatigue in Mountain Climbing}

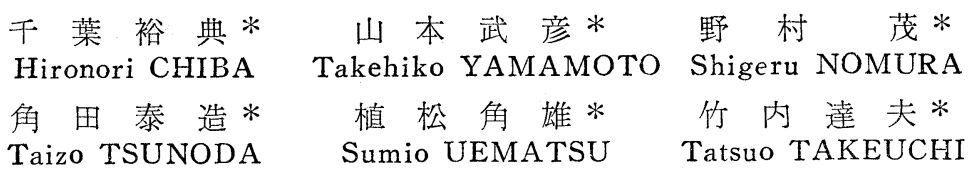

\section{緒言}

私達は昭和 32 年 8 月 6 日から 13 日までの 8 日間, 北

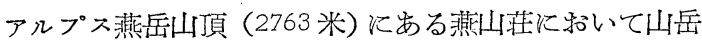
誩療従事するかたわら，登山者の疲労について実験的 考察をする機会があつたので報告する。

\section{袷 查方 法}

比較的山刀生活海慣れた健常者 (山需部学生, 山小屋 の番人）6名を対环群とし, 燕山荘を出発して大天井岳 (行程約 6 時間) を緹走せしめ, その前後を経時的潅 察した.

更に診陵所を訪れた一般登山者 33 名（男子 22 名, 女 子11名）は東京文は関西地方からの登山者で，大半の 人々流行にて北アルプスの登山口に早朝到着, 約 5 時: 間の登山を経て燕山荘に達し，一泊して後更に翌朝， 槍, 穂高を縱走する人々であった。

これらの人々について燕山荘到着㨁後と翌朝起床時の 二回に対照群と同じく種々の寒鈳調查を実施した。倚お これら一般登山者を医師つ診察つ結果:上，A 群：患者 に付添つて訪れた健常者， B 群：気分が悪いとか頭痛 がするなど特別な治㞠を必要とせず単に指示を与学るの みでよいと考穴られた軽症者群， C 群：救急処置など 適切なる処置と安静, 看護等学必要とした中等症者群仡 三大別し，比較検討々試みた。

\section{検 查、種 目}

i. フリッカー值の測定 1) 2)3)：学研式フリッカー測 定器を用い, 被検者の頭部から上半身を黑、衣で覆い暗 順応（約 15 分間）が充分沉得られた後 2〜3 回練習せし め, 第 1 回は先づテラッキ值を最高の 100 飞し漸次低下 せしめて，そのデラッキ始めを被祫者が認め得る点を読

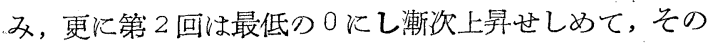
チラッキを認め得なくなつた点を読み, 筑3 回目は第 1 回つ操作を繰返し行つた。そしてその3 回つ実測值の平

* 順天堂大学医学部公臬徱生学教室 1958 年 10 月 23 日受付
均学とつた。3回の実澒值は大体一一致し2〜3 以内の誤 差しか讃められなからた。


腿にJが入らない状態にして, 滕関節の脛骨頭と滕蓋の 間の滕蓋腱つ中央部㕝（マーキロにて赤印を付した）膝 蓋腱反射閾測定器の明打檤を以つて打つ, 先づ角度計の $15^{\circ}$ より始めて漸次落下角を $5^{\circ}$ 程度づ増し 4 〜 秒刀

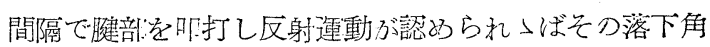
の前後を精查した。

iii. 尿ドナデオ反応検査 ${ }^{87}$.12) 13):

i. 試莧㳘 $4 \%$ モリブデン酸アンモン液, pH 5.6 とし 濾過して用いた (MA). 10000 倍のメチレン青液 (MB) メチレン青の 1000 倍液を貯え, 用比臨又10 倍して用い た。

ii. 術式：尿の稀瀵采列学つくる, 尿の採取は一定時 刻渄尿させ，その後排尿させた尿の量を測定し，その 間の時間 (分) で割ると1 分間当りの $\mathrm{ml}$ 数々なる, そ れを $\mathrm{a} \mathrm{ml}$ とすれば $\mathrm{a} / 2, \mathrm{a} / 3, \mathrm{a} / 4, \mathrm{a} / 5 \ldots . .$. を各凝集試 験管にとり水で $1 \mathrm{ml}$ にしてやると 1 分間, $2 \mathrm{ml}$ 尿, 3 $\mathrm{ml}$ 尿， $4 \mathrm{ml}$ 尿，……方出来る.それに $\mathrm{MB} 0.5 \mathrm{ml}$ 加光てよく振蕰し, ついで MA $0.5 \mathrm{ml}$ を加えよく振る・ 試薬を加光終つたら $37^{\circ} \mathrm{C} 1$ 時間放置した後, 弱遠心し て上清の色で判定した。

iii. 判定は, MB の60000倍つものを基準とし, それ 以上の浱度のもの学(十), 殆んで色わついてないるのを (一), 中間のものを（士）とした. 尿の濃厚ならちは, ずう一と（+）であるが，陽性物筫が少なくなると（一) そなつてしまう。その中間に（士）が一本位出ることが あるが，(+）の終りの稀釈度をとつて点数とした。

\section{実 験 成 績}

1 ドケデオ反応值：比較的山の生活沉慣れた健常者 について, 燕山荘到着後から翌日夕刻までの 6 回の尿に ついて絟時的炕観察してみると（図 1) の如く（短時間 の激しい労作の場合と異なり) 登山つ如き長持間认亘り 労作刀激しい持続的な負荷で法.911) 11) 15), 負荷解除後 


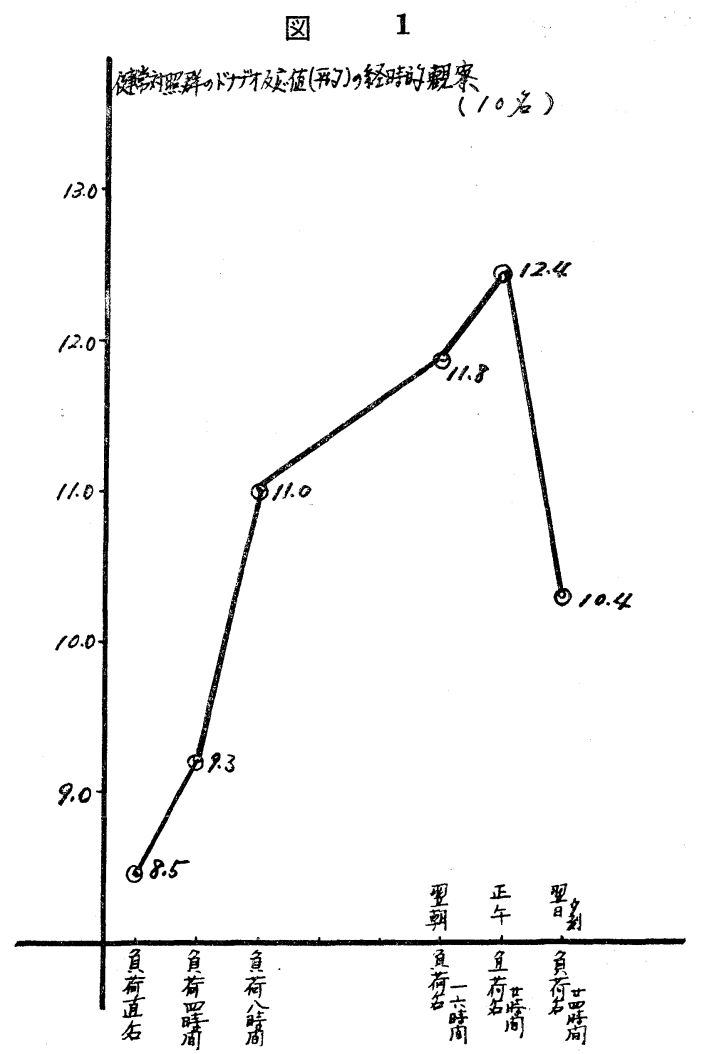

漸次上昇翌朝の 4 J 至 5 回目（登山到着後 12〜14 時間 後) に最大つピークを示し，その後は漸次下降するも翌 日夕刻に於ても未だ直後よりもな和高いようであった。

更に一般登山者の $\mathrm{A}, \mathrm{B}, \mathrm{C}$ 群について, 登山直後と 翌朝起床時つ尿のドナデオ反応值は（表 1）の如く, $x^{2}$ test による平均值の锂の検定を行つて A, C 群では その有意の差を具出すことが出来た。

表 1 各群别ドナジオ反応成績

\begin{tabular}{|c|c|c|c|c|}
\hline & & & 登山㨁後 & 禁日早朝尿 \\
\hline A & $\hat{s}$ & 12 & $8.55 \pm 1.28$ & $11.85 \pm 0.94$ \\
\hline B & $\hat{b}$ & 8 & $9.16 \pm 1.15$ & $15.30 \pm 1.08$ \\
\hline $\mathrm{C}$ & $\hat{\jmath}$ & 8 & $10.13 \pm 1.01$ & $17.56 \pm 1.45$ \\
\hline
\end{tabular}

2 フリッカー值：健常刘照群てついて, 䩢山荘到着 直後から歰朝起床持をでの経時的変動を観祭してみると (図 2) の如く，直後が一番低く滇次回復するが，登山 終了後3時間では未だ出発前の值には㕃らず 4) 5), 翌朝 始めて出発前值に回復するようであつた・即ち充分なる 睡抿がフリッカー值つ回復には主要なる因子であると考 えられた。
図 2 健常対照群のフリッカ一值 (本均值) の経時的钼祭（10 名)

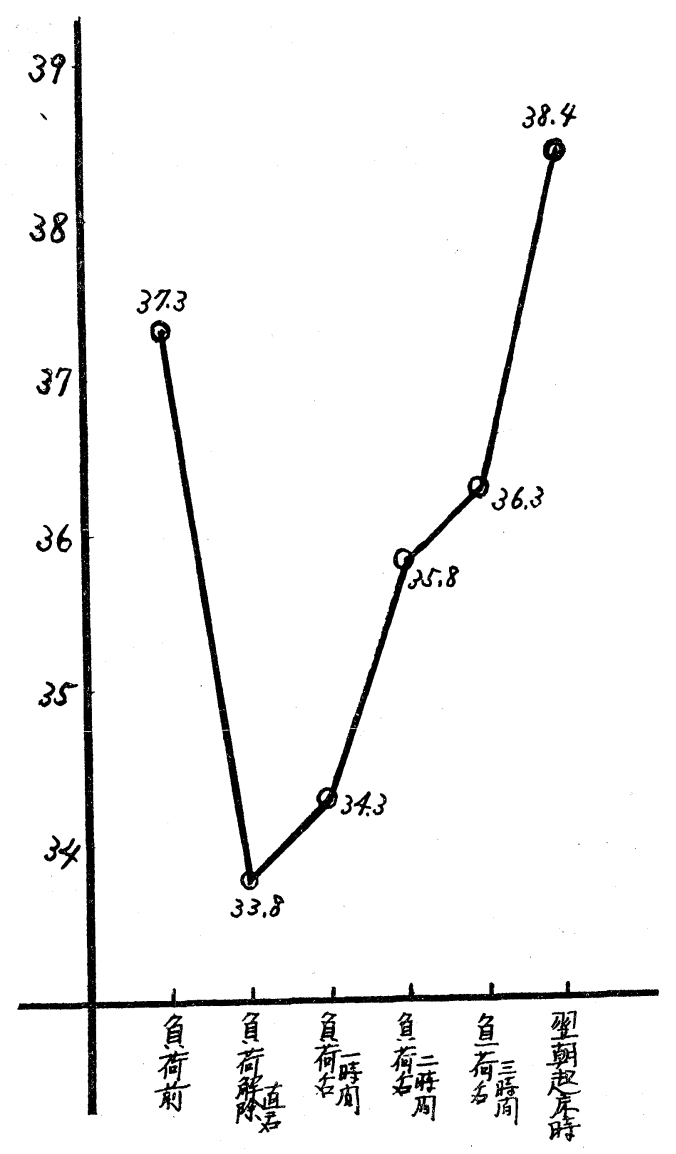

更に一般登山者てついては, 燕山荘到着直後と翌朝起 床時を比較し，疲学の回復引考えてみた。 A, B, C 群 別つ回復者数百分率な（表行）の如く，A，C 群間には $\chi^{2}$ test で有意差を認められたが，B 群では有意差が認 められなからた・な特性別の差異を検討してみると男子 28 名中, 翌朝起床時回復がみられたもの18名, 64\%, 女子 11 名中同じく回復がみられたもの僅か3名, 27.2

表 2 各群別フリッカー成續琵

\begin{tabular}{|c|c|c|c|c|c|c|}
\hline \multirow{3}{*}{ A } & \multirow[b]{2}{*}{0} & & \multicolumn{2}{|c|}{ 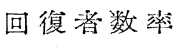 } & \multicolumn{2}{|c|}{ 非回復者数脊 } \\
\hline & & & 11 & $91.67 \%$ & 1 & $8.33 \%$ \\
\hline & 우 & 2 & 1 & $50 . \%$ & 1 & 50. \% \\
\hline \multirow{2}{*}{ B } & & 8 & 5 & $62 . \%$ & 3 & $37.5 \%$ \\
\hline & 우 & 5 & 2 & 40. $\%$ & $2(1)$ & 60. $\%$ \\
\hline \multirow{2}{*}{$\mathrm{C}$} & & 8 & 2 & $25 . \%$ & $5(1)$ & 75. $\%$ \\
\hline & 우 & 4 & 0 & $0 . \%$ & $3(1)$ & 100. \% \\
\hline
\end{tabular}


\%であつたが $\chi^{2}$ test で流, 性別づ差異は認められな からた。

翌朝起床時つ $\mathrm{F}$ 值つ回復が㯖いのは，かなりの遠方 から夜行列車にて登山口に到着し殆んど休息する眼もな くすぐ登山し始めるという前の条件が覀いこと, 登山と いう持続的で比較的長時間の激しい学作による強度の疼 労と環境の変化及び多くの人々が小さな山小屋飞雑魚寝 するため充分なる睡脏が取れなからた故と考完る・特儿 女性ではこの傾向が著明のようでした。

3 P.S.R. 值：健常対照群仙いてフッッカーと同じ く負荷前後を通じて, 経時的に 観察してみると（図3） の如〈 ${ }^{6)}$ 7), 負荷直後は著明に P.S.R. の間值は上昇す るが, 負荷解除後 1 時間ですぐさま負荷前の值に略々復 帰し，关の後は大さな変動をみない.これから P.S.R. は必ずしも睡眠や長い休息を必要とせず，たら゙単に1〜2 時間，足を休息せしめるのみで回復するためと考它られ た。

図 3 健常対照群の值 (平均値) の経時的観察

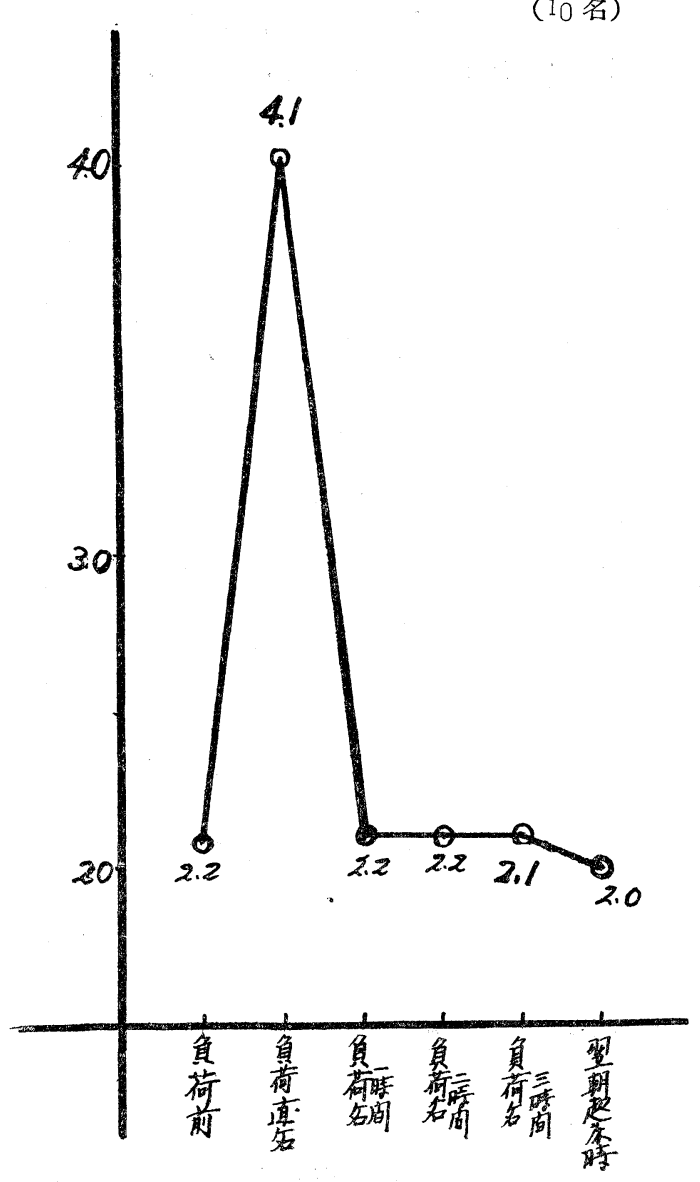

更に一般登山者沉ついて, 燕山荘到着直後と翌朝起床 時老比較してみると，A， B， C 群別の 回復者数百分率 は（表3）の如く，A 群回復者 14 名で100\%，B 群で は回復者 11 名で $84.6 \%, \mathrm{C}$ 群では回復者6名で50\%で めつた. A 群と C 群との間に $\chi^{2}$ test で有意の差を 認めた。な特性別の差異を検傠してみたが，男子 28 名 中回復者が 23 名で $82.1 \%$, 女子では 11 名中 8 名で 72.7 \%で $x^{2}$ test ではその有意の差を見出すことは出来なか つた.

表 3 各群別 P.S.R. の戚績装

\begin{tabular}{|c|c|c|c|c|c|c|}
\hline \multirow{3}{*}{ A } & & \multirow{3}{*}{$\begin{array}{r}12 \\
2\end{array}$} & \multicolumn{2}{|c|}{ 回復者数率 } & \multicolumn{2}{|c|}{ 非回復者数率 } \\
\hline & & & 11 & $91.67 \%$ & (1) & $8.33 \%$ \\
\hline & 우 & & 2 & $100 . \%$ & 0 & $0 . \%$ \\
\hline \multirow{2}{*}{ B } & & 8 & 7 & $87.50 \%$ & 1 & $12.50 \%$ \\
\hline & 우 & 5 & 4 & $80 . \%$ & 1 & 20. $\%$ \\
\hline \multirow{2}{*}{ C } & U & 8 & 4 & $50 . \%$ & 4 & 50. \% \\
\hline & 우 & 4 & 2 & $50 . \%$ & $1(1)$ & $50 . \%$ \\
\hline
\end{tabular}

以上主として客観的な実験成績について述べたが，一 般登山者についてはその他, 登山直前の一般条件, 産紧 疲労委員会案沙よる疲学症候調查, 垂液の $\mathrm{pH}$ 等につ いて調べてみた・それらの結果を実験成績を綜合的に考 觉てみると，

\section{考案及び結論}

1 疲学現象関しては今日未だ, 不明なる点が多く, 私達つ諸検査の成績も必ずしもパシレルではなかつた。 経時的追求からして明らかな如く, 諸検查が捕えたるの が疲労の一局面である点と，その特異なる回復課程を経

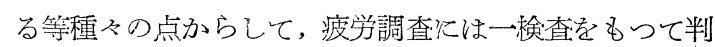
定することは至難で岕り，諸検查の結果:学綜合的飞考慮 すべきで第ろうと考党る。

2 ドナデォ反応：短時間の強労作を負荷した場合， 直後から 1 時間前後飞最高值を示し後, 桷次下降して約 数時間て安静值て 回復すると諸家つ報告が嵓るが 10) 11) 14) 15)，登山の如く長恃,間持:続的な强労作を必要とする 場合で注，直後より漱次上昇し翌朝 (18 時間後) に最高 值を示しその後は濑次下降して行くようであつた。

3 P.S,R.：実测值は個人美の範囲が広く疲学検查飞 は負荷前後を経時的に測定倹討すべきであると思う。 P.S.R. は笚飞足を休息せしめるのみですみやが回復 してくるようなので, 全身的な疲学よりも局所的な下腿 神筋系の疲学と考皇た方が妥当で离ると思う・な特 C 
群中の 数人に P.S.R. の回復がみられないものがいた が, これらの人は他の諸検查成績も甚だしく悪く, 強度 な疲学が加重蓄積された故と考觉てい〉と思う。

4 フリックー值：負荷解除後, フリッカー值は漸次 回復してくるが，二三時間その絽過を観察しつがけて も，負荷前の值には回復せず，充分なる睡抿が取られて 後, 初めて負荷前值飞完全佃復するようであつた。一 般登山者について, フリッカ一值つ回復が市まり良好で なかつたつは，山小屋に於ける睡抿の不良と激しい労作 による・過度の疲学のみならず，登山前の悪条件が大き く影響してきていると思う。

5 登山前の種々の条件, 前夜の睡抿, 食照, 気分, 行 程, 荷物等について, 前条件の悪いものほど疲労の程度 も高く且つ回復も悪いよ5であった。特沈肉体学作の激 しい登山ではェネルギー代謝と共儿発汗なぞ水分代謝も 盛んなので，下痢が疲学に与光る影響の多大なることを 認めた。

\section{文献}

1) 日本産業衛生協会, 産業㖫労委員会, 波労調查法, 1954.

2）日本産業衞生協会, 産業汯労検查の方法, 労慟の科
学, 第 7 卷, 第6 号, $89,1952$.

3）日本産業衙生協会, 産業淩労委員会, 波学制定のた めの機能検笪法, p. 239 247, 1957.

4）鈴木粮一郎, 塚原進, 東北医誌, 49 卷, p. 313 , 1954.

5）塚原進，東北医誌，46尞，p. 34，1952.

6) 浦本政三郎, 波学研究の共同実驗（創元社）， p. 14 $\sim 20,1950$.

7) 浦本政三郎, 厚生科学對刊 5 , 波学制定法, p. 17 $25,1947$.

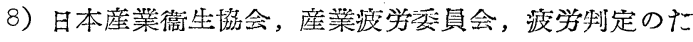
めの機能検查法, p. 121～124，1957。

9）宮下光子，体力科学， 7 怣第 2 昂, p. 54 59, 1958 。

10）蚛山達夫, 緗合医学, 10 兊, p. 255. 1953.

11）下川末夫, 日本生理誌, 55 等, p. $848,1953$.

12）佐藤德郎, 生体の科学, 1 爸, p. 39, 1949.

13）山添三郎, 社会医学裳卷, 13 , 菠学研労の共同実䛗, 創元社, 1950.

14）下川末夫, 体力科学, 3 卷 2 号, p. 64, 1954.

15）本田良行, 十全医誌, 56 卷, p. 16, 1954.

\section{Summary}

This paper is devoted to the report of an experimental observation of fatigue of mountain climbing. The observation was carried out at the hillside cottage on Mt. Tsubakuro, 2763 meter high when the auther engaged our duties as doctors there.

Experiment 1 . Observations were made in the time when they were going and returning from Mt. Tsubakuro to Mt. Daitenjo (about six hours on foot). The subjects were all healthy adults (ex. students or keepers of hillside cottage) who had acclimated themselves to mountain life.

In this experiment Donaggio reaction of the urine, Flicker-test and threshold value of knee-jerk (P.S.R.) were observed consecutively in taking a method of study group of fatigue of Japan Industrial Hygiene Association.

Regarding Donaggio reaction of the urine, Donaggio-value showed ascending tendency after the walk was over the maximum value was formed in the next morning and it was preserved in the same condition till the evening.

The minimum fall in flicker-value was observed immediately after the walk. It gradually restored and was at the recover on the following.

Regarding P.S.R, the maximum value was showed immediately after the walk and returned to. normality after one hour rest.

Experiment 2.33 cases visited the mountain clinic were amounted to 33 including 22 males and 11 females. All of them have come from Tokyo or Kansai district by night trains. 'The most part of them reached the foot of the mountain early in the morning and got to Tsubakuro hillside cottage. They tried to walk through Mts. Yari and Hotaka after one night stay at the cottage. 
Those 33 cases were divided into 3 groups according to the following matters;

Group A; normal (healthy adults in attendance on the invalids)

Group B; slight illness (needed to have a rest).

Group C; middle illness (needed an internal emergency treatment).

The authors made the same observation on fatigue that was tried in the experiment 1 . The results of the observation showed that to be worse in the order of group A, B and C.

Fatigue is generally understood that its nature and extent was formed differently according to the method of observation used.

The authors may consider that such observation made in this occasion can reveal, to some extent, the performance of methods of fatigue observation as well as the biological characteristics of fatigue itself. Because the present experiment was carried out onsuch continuous labour as mountain climbing uuder the condition of low atmaspheric pressure.

Depertment of Public Health, Juntendo Uuiversitg, Sehool of Meclicine. 